\title{
POPULAR RELIGION IN THE PERIPHERY. CHURCH ATTENDANCE IN 17TH CENTURY EASTERN FINLAND
}

\author{
MIIA KUHA* \\ University of Jyväskylä
}

\begin{abstract}
On the fringes of post-Reformation Europe, church and state authorities faced problems in enforcing church attendance. In the Swedish kingdom, religious uniformity was seen as vital for the success of the state after the Lutheran confession had been established, and absences from church were punishable by law. The seventeenth century saw significant tightening of legislation relating to church absences and other breaches of the Sabbath, and severe punishments were introduced. Despite considerable deterrents, it was sometimes difficult to control local inhabitants: absence cases were regularly brought before the local courts in Eastern Finland, where authorities were hampered by a combination of geographical distance and a highly mobile population. In this article, popular church-going practices are studied with an approach inspired by historical anthropology. In popular practice church attendance was required only on the most important holy days of the year, whereas on Sundays and prayer days, work or leisure were considered socially acceptable pursuits. Explanations of nonattendance should not only make reference to trying conditions: in certain situations people would travel long distances to church, despite the obvious difficulties they faced. Popular religious traditions and old conceptions of sacred time also affected behaviour among peasants. The great holy days of the year formed a ritual cycle, the aim of which was the maintenance of good relations with the supernatural. For the success of oneself and one's household, it was more important to follow the norms of popular culture than the orders of the authorities.
\end{abstract}

KEY WORDS: popular religion, popular culture, Reformation, 17th century, holy days

\section{Introduction}

The religious reformations of the sixteenth century affected the lives of thousands of people all over Europe. In the kingdom of Sweden, the Lutheran confession was adopted in 1527 and finally established at the Uppsala Synod of 1593. During the century that followed, Lutheran religion was taught through catechetic sermons and questionings in churches across the realm. All Catholic-based practices and other religious deviations were strictly forbidden. Religious cohesion was considered vital to the success of the expanding nation in its ongoing wars with neighbouring countries, and consequently, no deviation or even negligence of 
religious practice could be tolerated. The church and state co-operated in the implementation of control and discipline, and misdemeanours were harshly punished (Grell 2002: 271-274; Karonen 2008; Lehtinen 1961: 163-165; Gustafsson 2000: 111-113; Laine 1995: 133-135). However, recent research has questioned the traditional view that the church successfully transformed subjects into obedient Lutherans soon after the Reformation (Malmstedt 2002; Aronsson 1992). In fact, popular beliefs remained extremely persistent, and local circumstances could make it impossible to enforce strict discipline, especially in peripheral regions. In Eastern Finland, for example, popular church-going practices were in conflict with official church ideals. The clergy repeatedly complained that, although their parishioners did not go to church regularly, nevertheless on certain holy days of the year, such as Christmas and Midsummer, many were eager to attend and take communion. Because this kind of behaviour was considered superstition, it was seen as a notable threat to religious uniformity.

Regular church attendance by commoners was important to both the church and the state. At church clergy taught their parishioners the new religious doctrines, but it was also used by the state as an instrument of propaganda (Forssberg 2005). Furthermore, church attendance enabled the authorities to control what people did and how they behaved on holy days. There was a pronounced fear that more dangerous sins, such as magic, blasphemy and idolatry, might proliferate among those who were absent from church. According to collective understanding, the sins of only one individual could call God's wrath and vengeance down upon the whole country, and this legitimized increasingly strict forms of control and discipline (Malmstedt 1994: 193-204; Karonen 2014: 246; Eilola 2003: 17-18; Scribner 1997: 79-82).

The question of church attendance is closely linked to discussions about the reception of the Reformation among commoners. Through his 1975 study of German visitation records from the late sixteenth century, Gerald Strauss was able to show that the Lutheran religion had not yet made a strong impact on the large masses of uneducated people. Strauss argued that one of the main reasons for this was the persistence of traditional popular religion (Strauss 1975). ${ }^{1}$ The situation seems to have been quite similar in seventeenth-century Eastern Finland, where many ancient popular celebrations and rituals still existed in parallel with official and accepted religious practices.

This article focuses on popular church-going practices in seventeenth-century Eastern Finland. The interpretation of moral codes and meanings that lay behind popular behaviour is at the centre of the analysis inspired by historical anthropolbut the reception of the new doctrines by the wider population has remained on the agenda of Reformation research even though it has been considered difficult to assess through existing sources. See e. g. Marsh 1998: 9-16, 43-46. 
ogy. Surviving district court records and visitation records from the province of Savo (1639-1710) form the source material of the study. ${ }^{2}$ While it is not possible to establish the exact frequency of church attendance, the narrative sources provide rich detail and reveal something of the world in which they were written, specifically the limits and possibilities that faced the early modern peasant. When deciding whether or not to go to church, the Eastern Finnish peasant had many things to consider: length of journey, weather, outstanding work, orders by the authorities, potential punishment for misdemeanours, and last, but certainly not least, any possible effect on, or reaction of, supernatural beings.

\section{Limits of Control}

The necessity of attending church every Sunday was not obvious to all earlymodern Europeans. Before the Reformation, the sparsely populated but vast Eastern Finnish province of Savo (cca. $43000 \mathrm{~km}^{2}$ ) contained only three churches. Southern Savo gained a permanent settlement only in the late medieval era, and the northern area, over the course of the sixteenth century. During the seventeenth century, people were still moving to the unpopulated areas outside the province. In addition, proximity to the border zone between Sweden and Russia meant that wars and occasional raids occurred throughout the early modern era (DC Hiekkanen 2007: 534; Pirinen 1982: 265-308; Saloheimo 1990: 79, 161-176).

Consequently, at the time of the Reformation, there was only relatively loose contact between inhabitants and the Catholic Church. For the most isolated households, their 'local' church could be up to two hundred kilometres away. Although new churches were built in the sixteenth and seventeenth centuries, ongoing expansion of settlement to the north and west made it difficult for state and church authorities to control the inhabitants of Savo. Despite the churches that were built during the seventeenth century, a journey to church and back home could still take many days for some. Because people in Eastern Finland usually lived in remote single households (Pirinen 1982: 544-554; Saloheimo 1990: 144-153, 460-465), ${ }^{3}$ social control was much looser than would have been the case in a more densely populated settlement with a church at its centre.

In addition, mobility was a feature of the slash-and-burn farming that in seventeenth-century Eastern Finland was the main source of livelihood. A burned field could only produce crops for a few years, after which it would be abandoned and a new section of forest cleared in the same manner. In the sixteenth century, Savonians still tended to move their whole household when they burned a new area. When static households were later established, fields were, nevertheless,

2 These are the earliest available records of their kind from the province of Savo.

3 In the realm of Sweden, the independent peasantry formed a great majority of the inhabitants. Most peasants owned the land that they cultivated, and as a group, the peasantry also had representation in the Diet. 
scattered over such a large area that travelling to work could involve a rather long journey (Pirinen 1982: 51; Jutikkala 1958: 18-20, 87-88). Although this suggests that inhabitants were quite used to travelling considerable distances, the constant movement of people within a large area made it difficult for the state and church to exert control. Given these circumstances, it is perhaps not surprising that the clergy struggled to ensure church attendance.

\section{Requirements for Church Attendance}

Church attendance was not subject to very strict control in the sixteenth-century Swedish realm. The Church Ordinance of 1571 ordained that those who never or seldom attended church should first be advised to repent and if repentance was not forthcoming, be disciplined by both the church and the secular court (Church Ordinance 1571: 37-38). However, the penalties to be applied in various cases were not defined. Although the Church Ordinance of 1571 was not an actual church law and consisted mainly of liturgical guidelines, it formed the judicial basis of the church of Sweden for over a hundred years until a new church law was passed in 1686 (Parvio 1986: 97-98). In practice, during the first half of the seventeenth century, absence from church on a Sunday or another holy day usually resulted in a small fine of three marks, a sanction that had its basis in the medieval Land Law that continued to be used despite its official denouncement (Leppävirta 20.6.1648. KOa2: 747, NA).

By the early seventeenth century, God's law was increasingly understood to be identical to the Mosaic Law, and as a result the century that followed saw the harsh punishments of the Old Testament find favour and legal praxis tighten (Takala 1993: 13-18; Tamm et al. 2000: 29-31; Parvio 1986: 98-99). Obeying the Third Commandment-the sanctification of the Sabbath-meant participating in church services on Sundays and other holy days. The Church Law of 1686 and repeated ordinances against swearing and breach of the Sabbath (first in 1665 and again in 1687) marked a significant increase of control. All of these ordinances referred to God's law as the basis of the statutes (Church Law 1686; Schmedeman 1706: 441-463).

The first ordinance against swearing and breach of the sabbath, published in 1665, demanded, in accordance with the Ten Commandments, the sanctification of days of rest, which were detailed as Sundays, three (later four) annual prayer days and other specified great holy days of the ecclesiastical year. Sanctification was defined as the worship of God and the avoidance of all worldly tasks that could prevent or interfere with worship. Listening to and contemplating the word of God and the sermon were essential components of worship, as was regular taking of communion. The ordinance claimed that the many 'ungodly people' who intentionally absented themselves from church services were first to receive one or two warnings about their behaviour. Those who failed to repent were to be sentenced by the secular court and subjected to measures taken by the church. Be- 
cause the fine decreed in the ordinances was so large (40-100 marks), peasants were not usually able to pay and were instead subjected to corporal punishment or imprisonment, with their agonies compounded by church disciplinary measures (Schmedeman 1706: 456). Church discipline meant sitting in the stocks or in the penalty chair during the church service and, in more serious cases, public absolution in church. According to the contemporary notions of honour and shame, these were socially very harmful and degrading punishments (Sundin 1982).

The requirement of church attendance was also set out in the Church Law of 1686. The next year the law was supplemented with a new ordinance against swearing and breach of the Sabbath. The ordinance provided detailed instructions of the penalties to be imposed in cases of church absenteeism. First, the pastor was supposed to issue a warning to anyone who seldom or never attended church. After this, the absentee was to be reprimanded by the pastor and the elders of the congregation. If he still chose not to repent, the pastor was to give him one last warning, after which the offender was to be compelled to either pay a small fine or sit in the stocks. Should even these measures fail, a considerable fine was to be levied by the secular court (Church Law 1686). The paragraphs that specifically refer to absence from church seem to suggest that the more severe sanctions were only imposed in cases of persistent absence from church services. In practice, however, those who were punished for absenteeism were often sentenced under other sections of the ordinance against swearing and breach of the Sabbath (DC Kerimäki 16.-18.11.-1668. KOa1: 240, NA; DC Kerimäki 21.-23.11.1693. KOa4: 742-744, NA). If an individual absented himself from the church because he was working, travelling, or drinking - actions that the ordinance stated were forbidden on a holy day because they prevented the individual from going to church-he could be punished on these grounds (Church Law 1686; Schmedeman 1706: 457463). Thus, in the late seventeenth century, even a single church absence could potentially result in severe punishment. Even so, it seems that only a fraction of all church absentees actually found themselves in court. It is probable that the clergy used warnings and reprimands to deal with most offenders and only rarely passed cases of absenteeism to the secular court.

There was one exception to this trend: church attendance was controlled especially strictly on prayer days. Prayer days are a good example of how the state used the church to legitimize governmental actions. Because church attendance on prayer days was ordained by a separate prayer-day bill, sent out every year by the central government, it was a matter of particular concern for the secular authorities. Absence from church on a prayer day would lead straight to the court, where the most common punishment was a fine of forty marks. Such a sum was beyond the reach of most commoners, who had to suffer imprisonment or corporal punishment instead. The objective of prayer days was to bring people together in the churches to plead that God would spare the country from defeats in wars, 
diseases, famines, and other misfortunes. On the prayer-day bills, read aloud in churches, the king was represented as the protector of the realm. The success of the state was viewed as a sign of God's mercy, whereas misfortunes were seen as just punishment for the sins committed by the kingdom's subjects. The purpose of this kind of propagandistic message was to get people to obediently participate in the provision of resources that were required to sustain the constant warfare in which the expanding state was involved (Forssberg 2005: 80-86, 287-291; Malmstedt 1994: 94-106, 170-172; Scribner 1997: 82).

\section{Underlying Reasons for Church Absences}

In 1652 at the winter court of Iisalmi, a peasant was accused of not attending the most recent prayer-day service. When asked why he had not been present, the peasant explained that he had faced a long and difficult journey of eleven $\mathrm{mil}^{4}$ (5060 kilometres) along a bad road to reach Iisalmi church. He also claimed that he had only found out about the upcoming prayer day the previous day while working in his forest fields 5 to 10 kilometres from his home. However, a witness statement revealed that the peasant was not telling the whole truth. When the neighbouring household's mistress told him about the prayer day and urged him to attend, the defendant had replied: 'Let those go to the church who have time. I don't have time for something like that' (DC Iisalmi 12.-14.2.1652. KOa1, NA). His response reflects the reality of seventeenth-century Swedish peasants: working to secure crops and, thus, one's livelihood had to take priority, and all other duties, including attending church, had to take second place. Despite its truth, this reality was not to be acknowledged publicly. The peasant's utterance contradicted the predominant ideology (Vilkuna 2010: 7-8), so he had to pay a twenty-mark fine for his unguarded words. The sentiments that he tried to conceal from the court may have been shared by other absentees, but people were generally afraid to reveal such thoughts, for fear of attracting stricter punishment. This does not imply that commoners were totally indifferent towards the church, but that for many people travelling to church more than a few times a year was too demanding.

The inhabitants of Eastern Finland lived under extremely difficult conditions, and at times parishioners were probably unable to travel to church regardless of their wishes. Even if people had wanted to go to church more often, their intentions could easily be derailed by the daunting prospect of long and difficult journeys or by the demands of agriculture. Word of upcoming prayer days might also arrive too late to inform the entire parish. In the parish of Iisalmi in 1652, all ab- 
sentees were spared punishment after the vice-pastor admitted that even he, as a clergyman, had not received the information in good time (DC Iisalmi 16.18.6.1652. KOa1, NA). The journey to church could be extremely long and difficult, as the jury heard in the case of four men from the parish of Kuopio. The men, who had been absent from church on the second prayer day in August 1643, faced a long and trying journey to the church, during which they had to cross twelve streams. Despite this, the pastor thought that if they were not punished now, the offenders would not be motivated to mend their ways in the future, and as a result each man was ordered to pay the maximum fine of forty marks (DC Kuopio 21.-22.8.1643. KOa1: 286, NA).

According to the statutes, certain circumstances were seen as legitimate reasons for absences. The 1687 ordinance against swearing and breach of the Sabbath decreed that absence from church could be accepted on the grounds of weakness or illness, or if the defendant lived so far away that travelling entailed considerable inconvenience or hazard (Church Law 1686). As shown above, the judges were quite strict in determining whether the journey actually was so long and difficult that it could have a mitigating effect on the sentence. Illness and weakness were often reported as reasons for absence from church, but they were equally often used as excuses. In one case a defendant's brother and neighbour gave evidence that the man had been burning an area of forest on a prayer day and had not been ill, as he had claimed before the court (DC Kuopio 21.-22.8.1643. KOa1: $288 v$, NA). Many appear to have absented themselves from church in order to work. Three men brought before the Rantasalmi autumn court in 1639 were ordered to pay forty-mark fines (DC Rantasalmi 21. and 23.11.1639. KOa1: 15v, NA), as were fourteen men in Kuopio (DC Kuopio 2-3.12.1639. KOa1: 16, NA). Slash-and-burn farming, burning tar, and fishing were among the specific work activities cited as reasons for church non-attendance (DC Kuopio 21-22.8.1643. KOa1: 288v, NA; DC Rantasalmi 3-4.7.1648. KOa2: 773, NA; DC Kerimäki 5.-6. and 8.6.1696. KOa5: 86-87v, NA).

The defendant was expected to pay the entire fine unless he could provide a legitimate reason for his absence from church. However, a fine could be reduced in some cases. One peasant described how he started out for church on a prayer day, but his journey had been interrupted by bad weather after the first mile. The judge told the Puumala court that because the peasant had chosen to use a small boat even though he could have used a larger one, the defendant was partially responsible for the interruption of his journey. Accordingly he was required to pay a ten-mark fine (DC Puumala 19.11.1644. KOa2: 209, NA). This case illustrates the level of detail in the court proceedings, although the records of such hearings were usually rather brief.

Furthermore, records show that sometimes people just wanted to spend their holy day in leisure, drinking and resting from work. Drinking beer or spirits was a central part of the popular celebration of holy days, as was evident in some of the 
absence cases. Although attending a church service and drinking were not mutually incompatible, the use of alcohol could sometimes divert a traveller on his journey to church (DC Iisalmi 17-18.1.1654. KOa1, NA). In some instances, it seems that certain parishioners were spending time relatively close to the church with nothing particular to do, but still chose not to attend a holy-day service. When the bailiff of the parish complained that the local shoemaker had been seen strolling around between Sääminki and the neighbouring village during a prayerday service, the defendant was forced to admit that he could have come to church if he had so wished. This type of behaviour seems to indicate that some people did not view the observance of prayer days as particularly important. It may also suggest a collective understanding that it was enough for only part of the congregation to be physically present in church during the divine service (Malmstedt 2002: 160-161).

\section{Popular Code of Church Attendance: Absences}

The court and visitation records clearly show that people quite often failed to attend church in the approved manner. Although cases of church absences are not common in the district court records of Savo, they do appear with some regularity. For comparison, these cases were more common than witchcraft and magic trials, but a great deal less common than cases that dealt with property and landowning. During the fifteen-year period between 1639 and 1654, nineteen court cases related to church absences; these nineteen cases represented a total of at least sixty accused people. ${ }^{5}$ There is no apparent change in the frequency of absence cases about fifty years later. As late as 1693, the authorities received a report of a man who had not attended church for twenty-two years (Visitation Joroinen 1693. II Cd: 1, MMA). Absences from church services, communion, and visitations were reported fairly consistently in the visitations, though there was a slight decline in reported absences towards the turn of the eighteenth century (Kuha 2012: 5-6). Despite this slight change, it seems clear that the authorities faced ongoing problems in enforcing church attendance.

There is reason to believe that the cases brought before court were only the tip of the iceberg. In the sparsely populated province of Savo, the authorities found it very difficult to enforce strict discipline. When accused of absenteeism from church, people could find ways to stay away from the court, making it difficult for punishments to be enacted. At the district court of Rantasalmi in 1647, the chap-

$5 \quad$ This is the earliest period available for inspection. There were three different kinds of cases: sixteen cases dealt with absence from the church on a prayer day, two with absence on another holy day, and one with absence from the communion. It is not possible to establish an exact number of the accused. Records from one trial indicate that the vice-pastor presented a list of offenders but the number of accused is not mentioned (DC Iisalmi 16-18.6.1652. KOa1, NA). Most cases involved one to three offenders, but in one trial fourteen individuals were accused and twenty-two in another. 
lain presented a list of twenty-two individuals who had not taken communion for many years. None were present in court, and so the judge called on members of the jury and the wider parish to urge the violators to repent and change their behaviour before the next session of the court. Should this prove unsuccessful, the pastor was to report the case to the chapter and the accused would have to be imprisoned until they repented (DC Rantasalmi 8.-10.7.1647. KOa2: 556v, NA). However, it is possible that the accused were never punished: there was little to be done if offenders moved to newly settled areas that were beyond the control of the authorities. In some instances, court records mention that people fled from the province after having been convicted; such cases might not be brought before the courts a second time.

Poor knowledge of Christianity and low levels of general literacy among the peasantry might also indicate to low levels of church attendance. Literacy rates were increasing, but the literate population was by no means as widespread as was the case in Western and Central Europe. Before the turn of the eighteenth century, very few people in the province of Savo were able to read a book. Although the clergy were active in their teaching of the Catechism, the general base line of Christian knowledge was so poor that learning came about slowly. The first step was for everyone to learn the most common prayers and the Ten Commandments by rote. However, it was reported that in the 1670s even the Lord's Prayer proved too challenging for many in the parish of Kuopio (Visitation Kuopio 1670. II Cd: 1, JoMA). The number of people who could read began to increase only gradually over the course of the following century (Laine E and Laine T 2010).

A closer look at the sources reveals that patterns of church attendance differed according to type of holy day. There were three kinds of holy days when parishioners were supposed to attend church: Sundays, prayer days and other great holy days of the ecclesiastical year. Absence on a prayer day led to the involvement of the courts substantially more often than was the case on any other holy day. On the basis of court records, it seems that other cases of absence did not often reach the court's notice. Although some Sunday absences were brought before the courts, no absences whatsoever were reported during Christmas, New Year, Epiphany, Easter, Midsummer, and All Saints' Day. As well as being great holy days in the ecclesiastical year, many were also recognized as important holy days in popular culture. Of all the great holy days only a few absences were reported during Ascension, Whitsun, and Trinity Sunday. These were all celebrated in late spring, a very busy time of the year in terms of agricultural work. Peasants also celebrated a number of traditional holy days outside the church at this time of year, but it is difficult to say whether this might have affected church attendance. In both visitation records and court records there are fragmentary mentions of two popular holy days during the same season: the feast of Ukko (in late May or early June), based on ancient Finnish mythology, and St George's day (April 
23rd), the celebration of which included many rituals of popular tradition (Visitation Kuopio 1670. II Cd 1, JoMA; DC Sulkava 16.-17.1.1679. KOa2: 7-12, KA).

The greater number of prayer-day absences recorded in the district court records seems to indicate increased absenteeism, although it also reflects the stricter control exercised by the secular authorities on these days. Because of this, it is difficult to determine whether people actually wanted to go to church on prayer days or if they attended only because they were forced to do so. Given that prayerday absences led to more severe consequences than absences on other holy days, it seems probable that more people would have attended church on prayer days than at other times. In some cases, the records mention crowds of people at church on prayer days. However, the overwhelming number of prayer-day absences in comparison to other holy days does seem to indicate that there was some lack of interest in observing prayer days. These were new holy days added to the ecclesiastical calendar only after the Reformation, and it is possible that they had not yet been established as important holy days in the more remote regions such as Savo. They did not share the symbolic content of the traditional ecclesiastical holy days that were often closely linked to the natural year. All the prayer days of the year were observed during the summer season, between late April and September (Malmstedt 1994: 101). Because it was easier to travel even long distances to church along the waterways during the summer, difficult weather conditions had a more minor effect upon attendance than was the case at other times of the year. Furthermore, prayer days were celebrated on Fridays (Malmstedt 1994: 99). Friday was not a traditional work-free holy day, and it took time to introduce this new ceremony into the peasant calendar. In more central areas of the realm, it is possible that the position of prayer days had already become stronger. Although in the chapter records from Uppsala, Göran Malmstedt has found evidence of both respect and disregard for prayer days, it is respect that seems to prevail in his source material (Malmstedt 1994: 102).

On the other hand, very few entries refer to cases of Sunday absences. After the Reformation, the authorities accorded Sunday, as the Sabbath, a more central position at the expense of other holy days. Enforcement of Sabbath observance increased in the late seventeenth century, at the same time that the state reduced the number of other ecclesiastical holidays. However, the peasantry often carried on observing holy days that had officially been abolished (Malmstedt 1994: 106$114,231-236,239-244)$ and would place less emphasis than the authorities on the importance of regular Sunday attendance. We can see this in the visitation records, where the clergy often complain about church non-attendance on Sundays. Reports to the visiting dean or bishop indicate that the local clergy had some trouble in getting their parishioners to attend church on Sundays. The pastor of the parish of Kuopio complained that his parishioners "neither wanted to go to the church nor listen to the word of God' (Visitation Kuopio 1671. II Cd: 1, JoMA), while in the parish of Kangasniemi, the pastor reported that his flock was 
'very lazy to attend church' (Visitation Kangasniemi 1659. II Cd: 1, MMA). Nonetheless, it seems that, in practice, control of Sunday church attendance was rather limited. The clergy probably dealt with offenders without involving the secular authorities, but these matters would only have been discussed orally, and so no written documents would have been produced.

Interestingly, reported working on holy days follows the same pattern. Working on holy days was strictly forbidden on the basis of the statutes on swearing and breach of the Sabbath. Only necessary work could be performed after the church service. The accepted work was often women's work: tending the house, small children and cattle, and preparing food for the members of the household. Thus, it was men who ended up being accused of working on a holy day. In court records, working was most often reported on prayer days, along with a few cases of individuals working on Sunday and during late spring holy days. By contrast, working was never reported on holy days such as Christmas, Easter, New Year's Day and Midsummer. Thus, this follows the same pattern as the information that we have on church attendance. Abstaining from work was also an important way of sanctifying a holy day in popular culture (Malmstedt 1994: 41-42, 88-89; McClendon 1999: 16). If someone was found working on a holy day, this probably reflected a judgement about the perceived relative unimportance of a particular holy day.

An interesting detail revealed by the sources provides further confirmation that we can actually speak of a popular code of church attendance and not only of individual black sheep. Cases were brought to the court by the authorities, not by other peasants. There are only few cases in which the plaintiff is a private person rather than the rural police chief or the local pastor. In most of these cases, it is apparent that there was a pre-existing quarrel between the plaintiff and defendant, which means that complaints about church non-attendance could have been used simply as a means of taking revenge on a neighbour (e. g. DC Iisalmi 27.6.1648. KOa2: 756, NA; DC Kerimäki 5.-6.6. and 8.6.1696. KOa5: 86-87v, NA). Thus, it would seem that for the local community it may not have mattered very much whether someone was absent from the church service or went fishing on a prayer day.

\section{Popular Code of Church Attendance: Great Holy Days}

As we have seen, there were very few absence cases concerning other holy days of the ecclesiastical year, and it seems that the popular norm was to abstain from work on these days. The greatest holy days of the year were times when it was particularly important for commoners to go to church. The visitation records show that parishioners preferred to take communion on the most important holy days, and clergy across the realm complained about the way that people invaded their churches in large crowds on certain holy days. Most people specifically wanted to go to church and take communion at Christmas, Easter, and Whitsun 
(Aronsson 1992: 177-178; Laasonen 1967: 67-68; Lempiäinen 1967: 348; Malmstedt 2002: 138-139). This caused problems because the churches were not large enough to accommodate the entire parish congregation. In Kuopio, the situation escalated to the point where an old woman was killed as the crowd pushed towards the altar during a Christmas Day service (Visitation Kuopio 1670. II Cd: 1, JoMA). Many congregations in Savo actually forbade those who lived near the church to take communion on great holy days. However, these prohibitions proved ineffective, and the problem was raised repeatedly in parish visitations over a number of decades (Visitations Kangasniemi 1662, 1694, and 1707. II Cd: 1, MMA). The clergy objected to people taking communion only on certain holy days, because such behaviour was believed to indicate to the persistence of Catholic ideas among the people (Malmstedt 2002: 134-139).

In addition, the parish church of Kuopio was widely viewed as a sacrificial church, and people from up to nine surrounding congregations were known to travel to Kuopio to make their offerings. Offerings were most often made on certain annual holy days, particularly Christmas Day and Midsummer, the commemoration day of St John the Baptist, the patron saint of the church of Kuopio (DC Kuopio 26-30.6.1693. KOa4: 440-441, NA). Midsummer was also an important popular holy day and an ancient fertility feast, but while complaining to the court about the offering practice, the pastor of Kuopio specifically referred to the patron saint's day. Thus, it seems that the tradition in Kuopio at least partially represents the persistence of the Catholic-based tradition of celebrating the local patron saint's day (Pirinen 1991: 168; Juva 1955: 53-55, 107). The size of Savo province and the distances between parishes meant that not only did those who wished to make an offering in Kuopio have to go against the orders of the clergy and risk punishment, but they also had to travel very long distances. In the face of these difficulties, the effort had to be seen to be worth the risk by those who made offerings. The gifts that people brought to the altar suggest that their purpose was to secure success for different sources of livelihood. Information from other parts of the realm indicates that offerings were also given in order to recover from illness or gain protection for childbirth or a journey at sea (Weikert 2004: 146-150).

The authorities tried to regulate observance of holy days, but there were also popular norms that determined how people behaved on these days. Many reasons could underpin the choice to attend church on particular holy days. It was what their ancestors had probably done, and in a sparsely populated area, it was also a good occasion for meeting people. Drinking alcohol was also a central part of the popular celebration of holy days: people often drank beer and spirits just outside the church. Thus, the church was also a place for social life and entertainment. In addition, holy days had a special meaning in popular religion. In popular thought, great holy days were sacred periods of time, when the boundaries of the natural world became blurred and it was possible to have contact with the supernatural. The danger of being harmed in a supernatural way was enhanced, which 
made it necessary to behave according to special norms and prohibitions. However, it was also an opportunity to perform rituals to secure the future success and protection of oneself and one's household. The sacred was ambiguously understood as pure and respectable on one hand, and as dangerous and contaminating on the other. Therefore, holy days were times when people tried both to influence the future and to protect themselves by performing certain rituals (Douglas 2000: 54-55; Eilola 2003: 73-75, 136-137; Vilkuna 1956: 118-128; Stark 2002: 20-22; Östling 2002: 61-64). The church was regarded as a sacred space, where these kinds of rituals would have more effect. Taking communion or even participating in a church service could be understood as a ritual that would mechanically lead to God's blessing (Malmstedt 2002: 167). Thus, it was more important to attend church on the days that were thought to be more sacred than others, in spite of threats of strict punishment and public shaming.

The fact that parishioners continued to go to church, make offerings and take communion especially on great holy days indicates the importance of conceptions of sacred time in patterns of church attendance. The celebration of traditional holy days was linked to biblical stories or the worship of saints. They were also closely connected to the cycle of the agricultural year, giving them an important symbolic content. According to Scribner, these kinds of annual festivals provided a framework for human relations with the sacred. This means that on certain holy days, people concentrated on maintaining a good relationship with the supernatural. The celebration of annual holy days was related to two cycles, which worked to create sacred order in the world: the cycle of the ecclesiastical year and the cycle of the agricultural year (Scribner 1987: 1-3). Within the cycles, annual holy days were extraordinary periods, during which time was perceived to stagnate and lose its significance. The mythical past was relived and it was possible to have contact with the sacred (Eliade 2003: 91-92, 103; Östling 2002: 63-64). There was an important connection between the sacred and the community; this is most visible in the celebration of the most important holy days of the year, when the whole parish community gathered together at church.

\section{Conclusion}

This article has sought to analyse the ways in which both the physical environment and popular conceptions of the sacred and supernatural affected the relationship between the Lutheran Church and its parishioners in early-modern Eastern Finland. Church absences could easily be explained by reference to difficult living conditions and long distances, but these factors alone do not provide a complete picture. At certain times and in certain situations, people would travel long distances to church, despite the obvious difficulties they faced. It is evident that popular conceptions of holy days were closely connected to church attendance.

Enforcing church attendance was a central issue for the church and the state. It is impossible to ascertain the level of church absenteeism because we cannot de- 
termine how many people were beyond the control of the authorities. However, the trend towards stricter punishments towards the end of the seventeenth century demonstrates both that the authorities sought to tighten their control and that the people did not behave in ways promoted by the authorities. In the sphere of popular culture, holy days were times when certain norms had to be followed. They were times when it was more important to follow traditions, and thus secure a good relationship with the sacred, than to follow the orders of the authorities. The decision whether or not to go to church on a holy day was determined not only by the orders of the clergy, but also by the physical and social environment and the norms of popular culture.

The supernatural was an intrinsic part of the world-view of early modern people and it seems impossible to imagine that those who did not attend church just ignored the otherworldly altogether (see e. g. Eilola 2003: 90-94; Vilkuna 2010: 60-66). The commoners did not always go to church on a day they considered to be holy, and they seem to have had other ways of sanctifying these days. In the source material that has survived from the province of Savo, we can find information about popular holy days that still bore meanings of ancient Finnish mythology, and even an account of a zealous pastor cutting down sacrificial groves. In the syncretistic popular religious practice and world-view of Eastern Finland, Lutheran ideas blended easily with Catholic-based and even more ancient traditions (Siikala 2008: 185-186; see also Scribner 1997: 90). However, at this point, the church had already become the centre of the religious life of the commoners. The peasants embarked on the long journey to church in order to sanctify the holiest days of the year.

\section{Bibliography}

\section{Archival Sources}

The National Archives, Helsinki (NA)

District court records (DC)

Transcribed court records of the Pien-Savo jurisdiction 1663-1703 (KO a: 1-KO a: 10)

Transcribed court records of the Savo jurisdiction 1639-1653 (KO a: 1-KO a: 3)

The Provincial Archives of Joensuu (JoMA)

Kuopio rural parish archives

II Cd: 1 Visitation records 1670-1804

Leppävirta parish archives

II Cd: 1 Visitation records 1662-1841

The Provincial Archives of Mikkeli (MMA)

Joroinen parish archives

II Cd: 1 Visitation records 1693-1748 
Kangasniemi parish archives

II Cd: 1 Visitation records 1660-1794

II Ce Visitation records 1659-1840

Mikkeli rural parish archives

II Cd: 1 Visitation records 1700-1848

\section{Printed Sources}

[Church Law 1686] Kircko-Laki ja Ordningi 1686 (1986). In Hellemaa LI et al. (eds) Kircko-Laki Ja Ordningi: näköispainos ja uudelleen ladottu laitos vuoden 1686 kirkkolain suomennoksesta. Helsinki: Suomalaisen Kirjallisuuden Seura.

[Church Ordinance 1571] Then Swenska Kyrkeordningen 1571 (1971). In Kjöllerström S (ed) Den svenska kyrkoordningen 1571 jämte studier kring tillkomst, innehåll och användning. Lund: Håkan Ohlssons Förlag.

Schmedeman J (1706) Kongl. stadgar, förordningar, bref och resolutioner ifrån åhr 1528 in til 1701. Stockholm.

\section{Literature}

Aronsson P (1992) Bönder gör politik: Det lokala självstyret som social arena $i$ tre smålandssocknar, 1680-1850. Lund: Lund University Press.

Douglas M (2000 [1966]) Puhtaus ja vaara: ritualistisen rajanvedon analyysi. Tampere: Vastapaino.

Eilola J (2003) Rajapinnoilla: sallitun ja kielletyn määritteleminen 1600-luvun jälkipuoliskon noituus- ja taikuustapauksissa. Helsinki: Suomalaisen Kirjallisuuden Seura.

Eliade M (2003 [1957]) Pyhä ja profaani. Helsinki: Loki-Kirjat.

Forssberg AM (2005) Att hålla folket på gott humör: Informationsspridning, krigspropaganda och mobilisering $i$ Sverige 1655-1680. Stockholm: Stockholms universitet.

Grell OP (2002) Scandinavia. In Pettegree A (ed) The Reformation World. London and New York, NY: Routledge, pp. 257-276.

Gustafsson H (2000) Gamla riken, nya stater: Statsbildning, politisk kultur och identiteter under Kalmarunionens upplösningsskede 1512-1541. Stockholm: Atlantis.

Jutikkala E (1958) Suomen talonpojan historia. Helsinki: Suomalaisen Kirjallisuuden Seura.

Juva M (1955) Varsinais-Suomen seurakuntaelämä puhdasoppisuuden hallitsemina vuosisatoina. Varsinais-Suomen historia VII: 3-4. Turku: Varsinais-Suomen historiantutkimusyhdistys ry.

Hiekkanen M (2007) Suomen keskiajan kivikirkot. Helsinki: Suomalaisen Kirjallisuuden Seura.

Karonen P (2008) Reformaatio Ruotsin politiikassa. In Salminen J (ed) Reformaatio: henkilökuvia ja tutkimussuuntia. Helsinki: Suomen teologinen kirjallisuusseura, Suomen kirkkohistoriallinen seura, pp. 47-61. 
Karonen P (2014 [1999]), Pohjoinen suurvalta: Ruotsi ja Suomi 1521-1809. Helsinki: Suomalaisen Kirjallisuuden Seura.

Kuha M (2012) 'Jumalan sanan ylenkatsojat': rahvaan kirkossakäynti Savossa vuosina 1660-1710.J@rgonia 10(19): 1-18. See http://urn.fi/URN:NBN:fi:jyu201203211473.

Laasonen P (1967) Pohjois-Karjalan luterilainen kirkollinen kansankulttuuri Ruotsin vallan aikana. Helsinki: Suomen kirkkohistoriallinen seura.

Lehtinen E (1961) Hallituksen yhtenäistämispolitiikka Suomessa 1600-luvulla (1600-n. 1680). Helsinki: Suomen Historiallinen Seura.

Lempiäinen P (1967) Piispan- ja rovastintarkastukset Suomessa ennen isoavihaa. Helsinki: Suomen kirkkohistoriallinen seura.

Laine EM (1995) Papisto ja yhteiskunta Suomessa 1600-luvulla. Historiallinen arkisto 105: 131-177.

Laine EM and Laine T (2010) Kirkollinen kansanopetus. In Hanska J and VainioKorhonen K (eds) Huoneentaulun maailma: kasvatus ja koulutus Suomessa keskiajalta 1860-luvulle. Helsinki: Suomalaisen Kirjallisuuden Seura.

Malmstedt G (1994) Helgdagsreduktionen: Övergången från ett medeltida till ett modernt år $i$ Sverige 1500-1800. Göteborg: [G. Malmstedt].

Malmstedt G (2002) Bondetro och kyrkoro: Religiös mentalitet i stormaktstidens Sverige. Lund: Nordic Academic Press.

Marsh C (1998) Popular Religion in Sixteenth-Century England. London: MacMillan.

McClendon MC (1999) A Moveable Feast: Saint George's Day Celebrations and Religious Change in Early Modern England. Journal of British Studies 38(1): 127.

Östling PA (2002) Blåkulla, magi och trolldomsprocesser: En folkloristisk studie av folkliga trosföreställningar inom Svea Hovrätts jurisdiktion 1597-1720. Uppsala: Uppsala universitet.

Parvio M (1986) Vuoden 1571 kirkkojärjestyksestä vuoden 1686 karoliiniseen kirkkolakiin. In Hellemaa LI et al. (eds) Kircko-Laki ja Ordningi: näköispainos ja uudelleen ladottu laitos vuoden 1686 kirkkolain suomennoksesta. Helsinki: Suomalaisen Kirjallisuuden Seura.

Pirinen K (1982) Savon historia II: 1: Rajamaakunta asutusliikkeen aikakautena 15341617. Pieksämäki: Kustannuskiila.

Pirinen K (1991) Suomen kirkon historia 1. Keskiaika ja uskonpuhdistuksen aika. Porvoo: WSOY.

Saloheimo V (1990) Savon historia II: 2-Savo suurvallan valjaissa 1617-1721. Kuopio: Kustannuskiila.

Scribner RW (1987) Popular Culture and Popular Movements in Reformation Germany. London: Hambledon Press.

Scribner RW (1997) Reformation and Desacralisation: From Sacramental World to Moralised Universe. In Hsia R and Scribner RW (eds) Problems in the Historical Anthropology of Early Modern Europe. Wiesbaden: Harrassowitz. 
Siikala AL (2008) Myytit, riitit ja tietäjän toimet. In Räsänen R (ed) Savo ja sen kansa. Helsinki: Suomalaisen Kirjallisuuden Seura.

Stark L (2002) Peasants, Pilgrims and Sacred Promises: Ritual and the Supernatural in Orthodox Karelian Folk Religion. Helsinki: Suomalaisen Kirjallisuuden Seura.

Strauss G (1975) Success and Failure in the German Reformation. Past E Present 67: 30-63.

Sundin J (1982) Kontroll, straff och försoning: kyrklig rättvisa på sockennivå före 1850. In Sundin J (ed) Kontroll och kontrollerade: formell och informell kontroll $i$ ett historiskt perspektiv. Umeå: Historiska institutionen vid Umeå universitet.

Takala M (1993) Lex Dei-Lex Politica Dei: Lex Politica Dei -teos ja Kaarle IX:n lainsäädäntö. Helsinki: Suomen Kirkkohistoriallinen Seura, Suomen Historiallinen Seura.

Tamm D et al. (2000) The Law and Judicial System. In Österberg E and Sogner SB (eds) People Meet the Law: Control and Conflict-Handling in the Courts. The Nordic Countries in the Post-Reformation and Pre-industrial Period. Lund: Universitetsforlaget.

Vilkuna A (1956) Das Verhalten der Finnen in 'Heiligen' (Pyhä) Situationen. Helsinki: Suomalainen tiedeakatemia.

Vilkuna KHJ (2009) Neljä ruumista. Helsinki: Teos.

Vilkuna KHJ (2010) Katse menneisyyden ihmiseen: valta ja aineettomat elinolot 15001850. Helsinki: Suomalaisen Kirjallisuuden Seura.

Weikert M (2004) I sjukdom och nöd: Offerkyrkoseden i Sverige från 1600-tal till 1800tal. Göteborg: Historiska institutionen, Göteborgs universitet. 